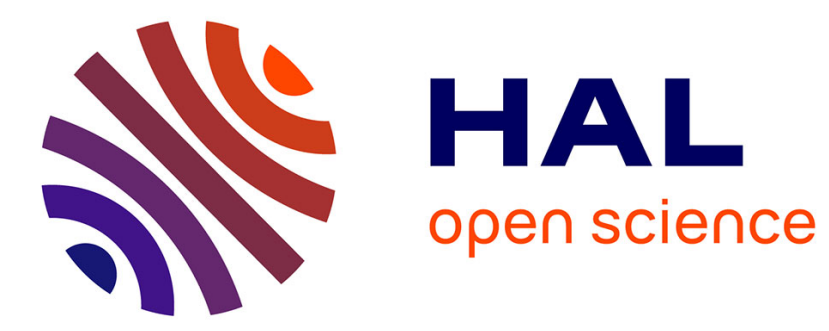

\title{
Brand conversation: Linguistic practices on social media in the light of face-work theory
}

\author{
Andria Andriuzzi, Géraldine Michel
}

\section{To cite this version:}

Andria Andriuzzi, Géraldine Michel. Brand conversation: Linguistic practices on social media in the light of face-work theory. Recherche et Applications en Marketing (English Edition), 2021, 36 (1), 10.1177/2051570720974511. hal-03049134

\section{HAL Id: hal-03049134 \\ https://hal.science/hal-03049134}

Submitted on 9 Dec 2020

HAL is a multi-disciplinary open access archive for the deposit and dissemination of scientific research documents, whether they are published or not. The documents may come from teaching and research institutions in France or abroad, or from public or private research centers.
L'archive ouverte pluridisciplinaire HAL, est destinée au dépôt et à la diffusion de documents scientifiques de niveau recherche, publiés ou non, émanant des établissements d'enseignement et de recherche français ou étrangers, des laboratoires publics ou privés. 


\title{
Brand conversation: Linguistic practices on social media in the light of face-work theory
}

\author{
Andria Andriuzzi, Coactis, Université Jean Monnet Saint-Etienne, France \\ Géraldine Michel, IAE Paris - Sorbonne, Université Paris 1 Panthéon-Sorbonne, France
}

\begin{abstract}
The rise of social media has resulted in brand-consumer interaction and more frequent conversations between consumers and brand representatives. To better understand how this "brand conversation" occurs, our research employs face-work theory and explores ambivalent consumer perceptions towards brand linguistic practices. Specifically, our results show how "threatening" messages (according to face-work theory) can be accepted by consumers, while "flattering" messages can be rejected. These paradoxical situations can be explained by brand relationships and the commercial and symbolic brand status. By identifying the specific features of brand-consumer interactions in the light of face-work, we propose a decision-making tool for brand management and community management practices.
\end{abstract}

Keywords: conversation, digital, face-work, brands, social media, norms

To cite this article:

Andriuzzi, A., \& Michel, G. (2021). Brand conversation: Linguistic practices on social media in the light of face-work theory. Recherche et Applications En Marketing (English Edition). https://doi.org/10.1177/2051570720974511 


\section{Brand conversation: Linguistic practices on social media in the light of face-work theory}

\section{Introduction}

With the aim of creating strong relationships with consumers, firms develop their brand's presence on social media outlets such as Facebook or Twitter (Hamilton et al., 2016). In addition to constituting a new channel to which objectives can be assigned, these tools offer brands the opportunity to communicate more horizontally, by plugging into networks of interpersonal relations (Fournier and Avery, 2011). A kind of conversation can then develop, at the initiative of brands or consumers. As such, we define a "brand conversation" as a series of messages exchanged online and in public between several individuals, one of whom openly represents a brand. Brand conversation can take place in spaces managed by the brands, such as their Instagram accounts, or in online spaces controlled by Internet users, such as consumer forums.

Given the wide variety of these situations, it is important for researchers and practitioners to identify the mechanisms behind a successful brand conversation. Several questions remain unanswered: which conversational models are used by brands on social media? How are these conversational models perceived by consumers? Answering these questions would make it possible to better understand how online brand conversations can engage consumers in interactions and relationships with brands and would thus respond to calls for new research on the content of online brand-consumer interactions (e.g., Villarroel Ordenes et al., 2019; Smith and Rose, 2020).

In order to analyse online conversations between brands and consumers, research has suggested that brand conversation could be seen as an element of a brand's expression driven by its values and consistent with its personality (Michel, 2017). In this context, it has been shown that brands that use personal pronouns generate more consumer involvement, compared to brands that do not use them (Cruz et al., 2017). Other work reveals that the use of emoticons by brands gives them a warmer personality ( $\mathrm{Li}$ et al., 2018), while consumers who are very familiar with a brand show more confidence when it uses informal language (Gretry et al., 2017). However, little is known about the linguistic rules that govern online brand conversation and how consumers perceive brands' respect for or transgression of these rules.

As brand conversation generally involves a human representative, often a community manager, and therefore interpersonal relationships (Griffiths and Mclean, 2015), this research proposes to use face-work theory, which makes it possible to precisely analyse interactions between individuals, from the point of view of both participants and spectators. The 
fundamental principle of face-work theory is that during an interaction, individuals attempt to save face while ensuring that others do not lose face (Goffman, 1955). The rules of behaviour then consist of mitigating face threatening acts (Brown and Levinson, 1987) and maximising face flattering acts (Kerbrat-Orecchioni, 1998).

Since the brand is an interlocutor unlike any other, the objective of this research is, from an exploratory perspective, to better understand the extent to which brands, as symbolic entities, use face-work rules in their online conversations and what the potential effects may be. To answer these questions, we conducted a qualitative study in the form of an online nonparticipant observation, analysing 151 conversations from six brands in three business sectors (automotive, food and beauty), and conducted a series of interviews with 12 consumers. These two approaches make it possible, on the one hand, to analyse the conversational practices of brands and the reactions of the consumers who participate in the conversations and, on the other hand, to become familiar with consumer perceptions of these conversations, whether they are participants or merely spectators.

Firstly, our results show that brands use different linguistic practices in accordance with face-work rules. On the one hand, they may seek to minimise any loss of freedom for their interlocutor by mitigating their "face threatening acts" (FTAs). On the other hand, they try to respond to consumer need for recognition by producing "face flattering acts" (FFAs). Secondly, our analysis reveals that brand relationships as well as the symbolic nature of the brands and the commercial context of these online exchanges with consumers explain how brand face threatening acts can be accepted and how brand face flattering acts are sometimes rejected. Our conclusions thus enrich the literature on brand-consumer interactions and extend face-work theory to the context of online conversations between brands and consumers. Finally, based on a typology of brand conversations, we make recommendations for brand management and community management practices.

\section{Theoretical framework}

\section{Conversations, a new mode of interaction for brands}

This research is part of the literature on brand-consumer interactions, which are based on three main dimensions: two-way communication, real-time exchanges and active control (Liu and Shrum, 2002). Online brand-consumer interactions between brands and consumers include different types of engagement between the two parties, such as likes, shares and comments. Within this variety of interactions, we define brand conversation as a series of messages 
exchanged online and in public between several individuals, one of whom openly represents a brand in any form whatsoever (logo, brand character, spokesperson, etc.).

Our definition includes verbal interactions with the brand (comments, discussions with brand avatars) within the scope of the brand conversation; furthermore, it excludes non-verbal interactions (e.g., likes, shares), non-public interactions such as private exchanges with online customer services (see Van Dolen et al., 2007) and interactions where the role of the brand is not clearly identified, such as when web users do not explicitly indicate their link with the brand (e.g., an influencer who would not disclose a partnership). This definition thus specifies the scope of the brand conversation, which in the past has often been used in a general fashion in the marketing field (Berthelot-Guiet, 2011; De Montety and Patrin-Leclère, 2011; Drouet, 2011) and gives a more detailed understanding of the various forms of conversation.

From this definition, and based on a review of the literature on brand conversation (see Appendix 1), we propose a typology of the different forms of brand conversation based on two criteria: the initiation and setting of the conversation (Table 1).

\section{[Insert Table 1]}

We have identified these criteria in the literature, where they are generally used independently of each other. With regard to the initiation of the conversation research has shown, for example, that user-generated content on social media is more often addressed to proactive brands, i.e. those that initiate conversations, rather than to non-proactive brands (Smith et al., 2012). With regard to the setting of the conversation, research addresses for example the fact that brand-managed spaces promote brand-consumer interactions, in comparison to consumer-managed online communities (Breitsohl et al. 2015).

Combining these criteria allows us to identify four forms of conversation: (1) A proactivehost brand conversation occurs when the brand launches a conversation topic within a space that it controls (e.g., on its Facebook page), offering consumers the opportunity to respond. (2) A reactive-host brand conversation occurs when internet users initiate a conversation in a space administered by the brand, which calls for a response from the brand (e.g., a co-creation website). (3) A proactive-guest brand conversation consists of brands intervening in a community space managed by consumers (e.g., an online consumer community) or by a third party (e.g., Tripadvisor), or even of reaching out to consumers posting on their own social media accounts without having explicitly addressed the brand (e.g., a personal blog, Instagram). 
(4) A reactive-guest brand conversation occurs when brands respond to opinions or questions from consumers who have addressed the brand from their personal account (e.g., Twitter).

\section{The benefits and risks of brand conversation}

Beyond research that focuses on the quantity of interactions, one is left to wonder about the real benefits of these conversations and the risks they may present. Consumers may get a form of gratification from interactions with brands (Simon and Tossan, 2018). Brands can effectively offer them opportunities to express themselves, and also to satisfy their ego (Smith et al., 2012). More specifically, brand responses to negative consumer opinions generates a certain satisfaction among consumers (Van Noort and Willemsen, 2012), all the more so when the comment is personalised (Wang and Chaudhry, 2018). Other research has also shown that the interactive nature of brand posts has a positive impact on consumers' intention to share information (Labrecque, 2014). More broadly, the literature shows that the more a brand interacts with consumers on social media, the better the relationship with the brand is and the more profitable the customer and sales become (Kumar et al., 2016).

However, the success of brands' approaches to interactions is not guaranteed. Thus, the positive effects of brand conversation must be qualified based on the individuals' engagement with the products or the conversation topic (Homburg et al., 2015). Moreover, brand responses that appear automated can provoke negative reactions (Labrecque, 2014; Van Noort and Willemsen, 2012). Similarly, excessive participation by a brand in consumer conversations can be perceived as intrusive and damage attitudes towards the brand (Homburg et al., 2015).

To better understand how consumers react to brand conversation, it seems essential to analyse the different forms of conversations used by brands. Research has already demonstrated that brands that use language-based humanisation techniques, such as the use of first-person (Chen et al., 2015) or second person (Cruz et al., 2017) personal pronouns, generate more consumer participation and engagement compared to brands that do not use them. Other studies show that the use of emoticons by brands gives them a warmer personality that is appreciated by consumers ( $\mathrm{Li}$ et al., 2018), while consumers who are very familiar with the brand appreciate informal language more than formal language (Gretry et al., 2017). More generally, brand messages with emotional or informative content are more frequently shared by consumers than prescriptive messages (Villarroel Ordenes et al., 2019). 


\section{Brand conversation and face-work theory}

Despite the significant nature of the research mentioned above, little is known about the interpersonal mechanisms at work in brand conversation. More specifically, Smith and Rose (2020) emphasise the need to study the role of norms in online brand-consumer relationships. Thus, in order to better understand brands' conversational practices, we use face-work theory, which enables the detailed study of such norms by revealing an "interaction order" (Goffman, 1973). Face-work theory also makes it possible to take into account both the participants in and viewers of conversations that take place in a public space (Kerssen-Griep et al., 2008).

Originating from sociology and linguistics, face-work theory was developed by Goffman (1967) before being expanded notably by Brown and Levinson (1987) and Kerbrat-Orecchioni (2005). It is based on the fundamental idea that, during an interaction, individuals focus on saving face while preventing others from losing face (Goffman, 1955). According to Goffman (1967), face corresponds to the positive social value that a person acquires through the approach that others assume he or she has adopted during a particular contact. To respect the order of interaction, or in other words to ensure that interactions take place in a satisfactory manner for all parties, individuals seek to satisfy two fundamental needs: to be free and to be recognised (Brown and Levinson, 1987). To achieve this delicate balance, they implement a complex range of linguistic practices, catalogued in a politeness theory that makes face-work a universal principle of all human communication (Brown and Levinson, 1987).

Faced with individuals' need for freedom and autonomy, prompts such as orders or suggestions can encroach on the other person's territory. Similarly, impositions such as gifts or suggestions can make the person feel obligated. Face-work theory thus focuses on "face threatening acts", or FTAs (Brown and Levinson, 1987). Nonetheless, when the occurrence of threatening acts proves inevitable, individuals may mitigate their negative impact, for example by using an interrogative form, offering several options or depersonalising their statements (Brown and Levinson, 1987). Furthermore, to satisfy their interlocutors' need for recognition, individuals may seek to "give face", for example by complimenting or being sympathetic. These "face flattering acts" or FFAs (Kerbrat-Orecchioni 2005) may also consist of trying to cooperate with the other person by seeking to include them or by showing optimism.

The implementation of these interaction strategies is outwardly complex: the response to a need for validation (e.g., offering a gift) can both satisfy this need and threaten a desire for autonomy. The coexistence of two opposing tendencies, integration and independence, makes the semantic duality of any social interaction inevitable (Goffman, 1967). This is why individuals also use contextual assessment criteria to identify the level of risk of "losing face" 
and define the appropriate interaction strategy for a given situation (Figure 1). Brown and Levinson (1987) take into account the act's degree of imposition, i.e. the "severity" of the threat to face in a given culture, as well as the social distance and any power relationship that exists between the interlocutors.

\section{[Insert Figure 1]}

More recently, researchers have studied how face-work manifests in online interactions, whether in forums or on social media (Bedijs et al., 2014). For example, when Internet users ask to join a discussion group and then see their request rejected and criticised, their desire for recognition is unfulfilled, which generates negative feelings (Chen, 2015). Similarly, Internet users' social media posts can hinder their friends' desire for autonomy, for example by offering them insistent and unsolicited advice (e.g., "Go see the new Tarantino!!!"). Individuals then use an avoidance strategy that aims to save face for their interlocutor (Mauney and Jeon, 2014).

Since brands generally express themselves through a human spokesperson (e.g., a community manager) and on platforms designed primarily for individuals (Fournier and Avery, 2011), it can be assumed that face-work rules also apply in this context. However, since the brand is not an interlocutor like others, these rules may be applied according to specific rules. This research therefore aims to better understand brands' conversational practices and consumer perception of them based on the linguistic rules employed by the brands.

\section{Methodology}

We propose to study brand conversation from the perspective of face-work theory, while considering several types of players (brands, participating consumers and spectators), different contexts (several social media channels) and several types of brands (products and services; Table 2). To identify the different linguistic practices used by brands and to study the behaviour of consumers who participate in conversations, we undertook a non-participant observation of online conversations between brands and web users, based on a collection of 151 conversations involving six brands in three business sectors. In addition, to better understand the perceptions of consumers, whether they participate in the conversations or are merely spectators, we interviewed 12 consumers in semi-structured individual interviews.

[Insert Table 2] 


\section{Qualitative study of brands' online conversational practices}

We conducted a non-participant observation of data published online by brands and consumers, inspired by multi-site virtual ethnography (Bouillé et al., 2016; Hine, 2007). To conduct a study based on online data, it is necessary to ensure that a sufficient volume of data is available (Kozinets, 2010). To this end, we selected "well-known" brands in sectors where internet users are particularly active. Given that consumers who interact with brands are in the minority (Campbell et al., 2014), we were more likely to be able to identify brand conversations by choosing well-known brands, since they by default produce a greater number of consumers than little-known brands. To identify "well-known" brands, we crossed-referenced three sources indicating a certain level of awareness: most-purchased brands ${ }^{1}$, preferred brands ${ }^{2}$ and brands with the highest financial values ${ }^{3}$.

In addition, to further improve the conditions for our collection, we targeted business sectors where consumers are particularly active. Since the consumer goods sector features highly engaged consumers (Dessart et al., 2015), we chose two product categories: nonalcoholic beverages and hygiene/beauty products. A third category, automotive, was chosen due to the particularly strong consumer involvement in online brand communities (Hutter et al., 2013). Finally, we chose two brands in each of these three categories, with the aim of observing a certain range of different situations: Carte Noire and Joker, Guerlain and Le Petit Marseillais, and Audi and Peugeot respectively.

This desire to gather a wide range of interaction situations follows the principles of "unsystematic naturalistic observation" (Goffman, 1973, p. 17). This method consists of immersing oneself in a given context - here, that of social media users who are conversing with brands, and collecting data in the field without intervening, in order to avoid changing the subject behaviour, and prioritising the diversity and relevance of situations rather than their completeness. We thus carried out research on the main social media channels (Facebook, Instagram, LinkedIn, Twitter, YouTube) and on the sites of some brands that feature blog-type sections (e.g., Peugeot, Carte Noire) and forums (e.g., Le Petit Marseillais). Collection was paused when analysis of the corpus revealed theoretical saturation (Glaser and Strauss, 1967).

\footnotetext{
${ }^{1}$ Kantar Worldpanel Brand Footprint Study, 2015. Sources: LSA. http://www.lsa-conso.fr/les-50-marques-les-plusachetees-en-france-sont,210031 and Brandfootprint: http://www.brandfootprint-ranking.com/\#/explore-the-data

${ }^{2}$ Toluna Study for Le Grand Livre des marques, 2015. Sources: Challenge http://www.challenges.fr/entreprise/20150130.CHA2665/quelles-sont-les-marques-preferees-des-francais.html and LSA http://www.lsa-conso.fr/quelles-sont-les-marques-preferees-des-francais, 199012

${ }^{3}$ Brand Finance study, 2015. Source: LSA http://www.lsa-conso.fr/les-marques-les-plus-puissantes-au-monde-eten-france-selon-brand-finance-infographie, 201790
} 
The chosen analysis unit, "one conversation", describes at least to two successive messages, one of which is written on behalf of a brand. Of the 151 conversations collected, 117 were initiated by a brand and 34 were initiated by a third party. These conversations include a total of 5,214 comments $^{4}$, an average of 34 comments per conversation $(\min =1 ; \max =931)$. The collected content totals 341 pages and 137,292 words.

These data were analysed at two levels. The first level consisted of carrying out a content analysis, encoding, depending on the case: (1) the conversation as a whole; (2) a "speaking turn", i.e. the intervention of a participant from the time they begin speaking until another takes their turn (Sacks et al., 1974) $)^{5}$; (3) an "adjacency pair", i.e. two speaking turns constituting a sequence (e.g., a question and its response; Schegloff and Sacks, 1973). The encoded semantic units were identified through repeated and in-depth consultations of the data. They were grouped into categories and sub-categories that were developed and organised throughout the analysis using an inductive approach (Bardin, 1977). Codes corresponding to concepts derived from face-work theory were then used, namely FTAs, mitigations and FFAs, with the aim of studying the context of their appearance.

The second level of analysis consisted of deepening the study of the conversations, following the principles of conversation analysis (Schegloff and Sacks, 1973; Sacks, Schegloff and Jefferson, 1974; Kerbrat-Orecchioni, 2007). Developed through the study of face-to-face interactions between individuals, conversation analysis is a current of research in linguistics that focuses on the smallest details of the conversation to reveal a structure within the interaction (Goffman, 1973). It pays particular attention to the way in which "speaking turns" and their combinations are organised into "adjacency pairs", concepts already mobilised in our coding phase.

To illustrate our results, we have opted for a transcription of online conversations modelled on conversation analysis transcriptions of face-to-face conversations (e.g., KerbratOrecchioni, 2007), rather than for screenshots. This presentation format makes it possible to respect the anonymity of consumers in order to protect them against an unethical use of public online data (Godes and Mayzlin, 2004; Kozinets, 2010). In addition, the numbering of speaking turns makes it easy to refer to them when presenting the results.

\footnotetext{
${ }^{4}$ Number estimated based on the functionalities offered by the different platforms. The number of comments noted was either that indicated under the initial post (e.g., Facebook, LinkedIn, YouTube), or that recorded during manual counting (e.g., Instagram, Twitter). Our estimate is low due to the way comments are displayed on Facebook pages, which at that time indicated only the number of comments but not the "replies to comments".

${ }^{5}$ The equivalent of a speaking turn, on social media, may be a post or a comment.
} 


\section{Semi-structured interviews with consumers}

In addition to studying online data, we conducted face-to-face interviews with twelve consumers to benefit from a more in-depth understanding of consumer perceptions of brand conversation and with the aim of triangulation. In addition, as our study focused on consumers who participate in brand conversations as well as the majority who only observe them, an analysis of the participants' online behaviour was not sufficient to understand the perceptions of spectators.

We used a convenience sample using age and gender as selection criteria. Demographic characteristics can in fact lead to specific reactions to marketing operations on social media (Campbell et al., 2014). Two women and two men were thus chosen from each of the following three age groups: 18 to 34 years, 35 to 59 years, 60 years and over. We also paid particular attention to a range of socio-professional categories (Table 3 ).

\section{[Insert Table 3]}

The semi-structured interviews were based on an interview guide organised around three themes: (1) the presence of brands on social media, (2) the observation of exchanges between brands and consumers and (3) any participation in such exchanges. At the end of the interview, stimuli were presented to provoke the respondents to react to different types of brand conversation, in the form of screen shots. We selected four stimuli based on the richness of the content and the diversity of the interaction situations. Each of these stimuli represents one of the categories of our typology of brand conversations (see Table 1), respectively: (1) a post by the Caisse d'Epargne bank on Facebook followed by comments from Internet users; (2) a discussion thread on the MyStarbucksIdea co-creation website; (3) a tweet by the Gaumont Pathé cinema chain addressing a consumer; (4) an exchange between the Free Mobile telecommunications operator and a consumer needing technical assistance on Twitter. Since our online data collection focused on product brands, we have prioritised service brands here, in order to improve the diversity of cases studied.

The interviews lasted from 58 minutes to 1 hour and 34 minutes ( $M=1$ hour 12 minutes). They were recorded and then transcribed in full. The final corpus totals 266 pages and 93,655 words, or an average of 22 pages and 7,805 words per interview. We analysed the interviews using inductive encoding. The codes were determined over the course of the analysis, based on the emergent meaning of the verbatim statements and without being defined in advance based on the literature (Arnould and Wallendorf, 1994). The analysis of the interviews was 
triangulated between the researchers. They compared and discussed their analyses in order to reach a common understanding (Goulding, 1999).

\section{Results}

Our results show how brands use face-work rules in their online conversations and how their FTAs, mitigations and FFAs produce ambivalent perceptions and reactions among consumers.

\section{Production and mitigation of FTAs in brand conversation: from reluctance to engagement}

Production and mitigation of FTAs by brands. On social media, brands seek consumer engagement and participation, specifically to optimise brand-consumer relationship quality (Hudson et al., 2015). Paradoxically, this often results in the production of linguistic acts that, according to face-work theory, risk damaging the face of their interlocutor and therefore compromising the pursuit of harmonious interaction. Based on Brown and Levinson's typology of FTAs (1987), the analysis of the collected brand conversations reveals two forms of FTAs associated with seven linguistic practices (Table 4).

\section{[Insert Table 4]}

Brands frequently use calls-to-action, suggesting that consumers do something (e.g., "Discover..."), taking the form of advice or even sometimes orders (e.g., "LIKE, COMMENT or SHARE”). In another, perhaps more subtle way, brands "impose" themselves on consumers through gifts or promises (e.g., "obviously, you'll love it"). Beyond the desire to create engagement with the product or brand, FTAs sometimes have a more functional role, in the case of warnings or requests, which can in particular help internet users resolve customer service problems.

Furthermore, FTAs are often associated with phrases that, according to face-work theory, aim to mitigate their potentially negative significance. Based on Brown and Levinson's typology of mitigations (1987), our data analysis reveals three forms of mitigations associated with six linguistic practices (Table 5).

\section{[Insert Table 5]}

To mitigate their FTAs, brands may seek to offer several options rather than impose a single solution. They may also choose to depersonalise or generalise their statements, or to make a suggestion in the form of a question rather than an order (e.g., "Can you figure out the 
exact number of oranges?" rather than "Count the exact number of oranges!"). However, we have noted contrasting perceptions regarding the use of FTAs and their mitigation.

Perception of FTAs and their mitigation: reluctance and engagement. By their very nature, brand FTAs risk eroding consumers' sense of freedom by encroaching on their territory (Goffman, 1973). Specifically, brand call-to-actions, most often orders according to our typology of FTAs (see Table 4), do seem to exacerbate consumers' criticisms, as demonstrated in Guillaume's account:

"It's often calls. (...) "Click here to win a free Samsung phone, only 400 left, don't wait", stuff like that. It's just to make you click so then you'll get messages from Samsung or another brand. (...) For me it's all just trickery, I don't know how to explain it. It's not very healthy, you know. That's often how it goes. "Click here, click on this", it's the imperative. It repulses me. The thing is, people will click if they want to." (Guillaume).

Guillaume's criticisms are particularly strong when it comes to "sponsored posts"6 on Facebook from brands with which he is not particularly familiar. In the same vein, a conversation initiated by Audi on its Facebook page also shows that some consumers do not accept orders from brands on social media:

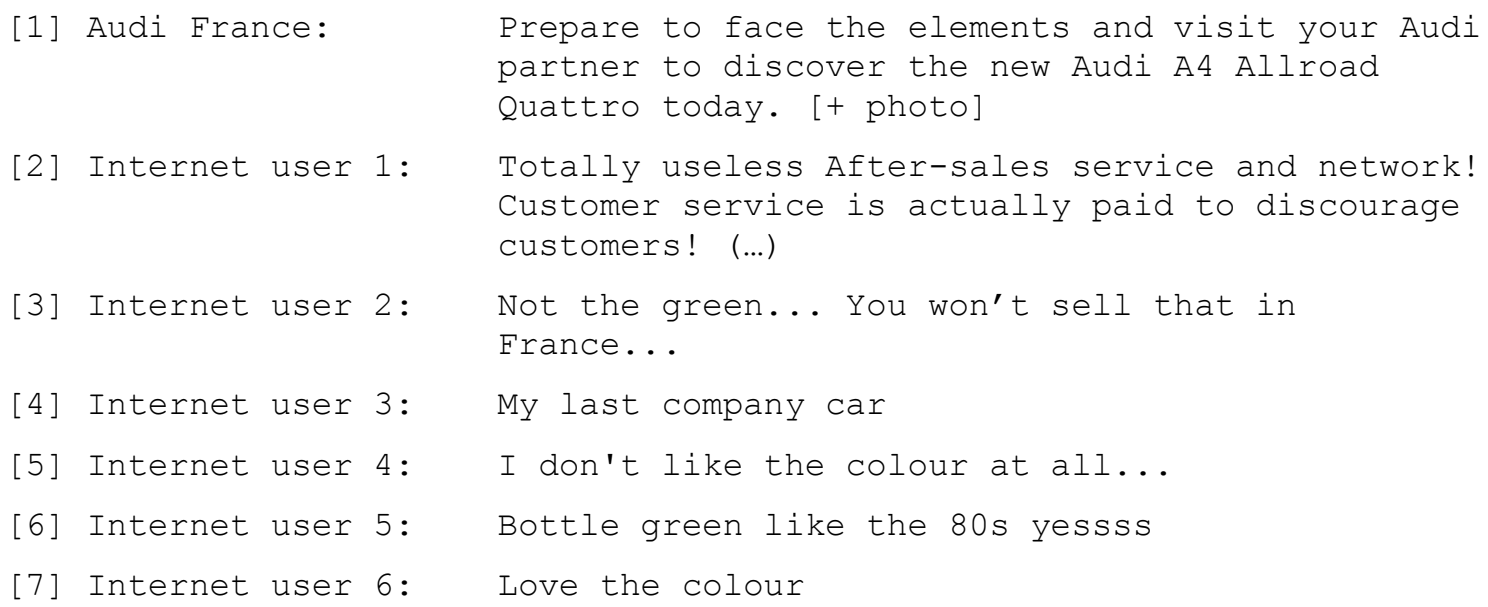

The initial Audi message, in the imperative, contains a warning ("get ready to...") and an order ("visit..."). Its potential negative impacts are neither mitigated nor balanced by an FFA. In this case, consumers blame the brand (turn 2) and openly disapprove of the model presented (turns 3 and 5). These reactions are like a defence mechanism (Zemack-Rugar et al. 2017) against assertive messages from brands. However, consumer reactions are rarely unanimous.

\footnotetext{
${ }^{6}$ Sponsored posts are messages posted by brands that use the same conversational devices as their usual social media posts, but can reach a wider audience than just the brand's followers, depending on the budget allocated to their distribution.
} 
Here, other consumers react more neutrally (turn 4), ambiguously (6) or favourably (7). This range of reactions suggests that, faced with an FTA, consumers oscillate between reticence and engagement depending on their familiarity with the brand. Thus, Justine shows how her knowledge of the brand allows her to accept this aggressive conversational mode without it threatening her desire for freedom:

"I'll admit that I'm not a big shopper.... Oh yeah, I added clothing designers on Facebook, because I liked them. (...) You get the impression that you're not the one deciding anymore. And I prefer that, yeah. (...) A little thing once a week like that that reminds you, saying: "oh yeah, that's right, they exist, there's a handbag, I'm going to go look at the new handbag collection." It'll just make me think and then it's up to me to click and go look. And then I forget the first time, and then I forget the second time, and then because there's one per week... One per week, eventually I'll end up going to look when I need the bag or the...(...) It can't be intrusive, otherwise it can be counterproductive... We can just relax on Facebook with our friends, be left alone". (Justine).

This account shows that an FTA is not necessarily perceived as intrusive when consumers have chosen to follow the brand beforehand and therefore do not feel they are in a situation where they risk losing face. This is also the case for Marina, who describes her interest in suggestions posted by museums that she follows on Facebook:

"I follow lots of museums, for example the European House of Photography, and also a museum in New York specialising in photography. Because I like to know... Or the Tate Gallery, things like that (...). By doing that I stay informed about what's happening at each art gallery for example (...) It's not invasive, not at all. And that's great. It's cultural content related to the artists that are displayed at the institutions, that's all. (...) Museums don't ask us to do things, right... It's just a suggestion. To have fun, to learn, that's all. (...) [I may comment], yes, if the subject is of interest to me. If I know the subject well and I'm not going to say anything stupid. If I think it is important or relevant, yes." (Marina).

Here, the respondent perceives the motivational messages of the brands spontaneously as suggestions and considers them acceptable or even welcome. The risk of face loss caused by FTAs, even if they are commanding, seems limited here insofar as Marina has a relationship of trust or even recognition with these brands that alert her to cultural experiences. Although FTAs, in certain situations, can be issued without damage, face-work theory indicates that when a risk of face loss is present, it is desirable to mitigate it by using appropriate phrases. In the following two examples, brands take certain precautions to mitigate their calls-to-action. Thus, in a first example, the Audi brand encourages Internet users to watch a video on YouTube: 
In a second example, the Carte Noire brand encourages people to discover its new range of capsules on Facebook:

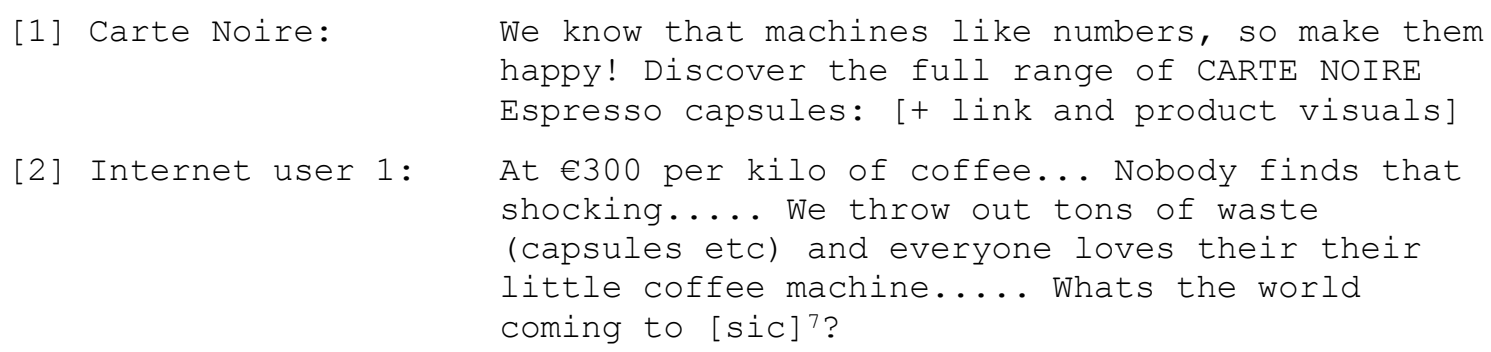

The Audi and Carte Noire brands use the imperative mode specific to the "orders" of our typology (table 4), but simultaneously incorporate several phrases that mitigate the potentially negative effects of these commands. In the first example, Audi uses the questioning form "What if?". In addition, the pronoun "we" marks a depersonalisation that protects people by allowing them to be included in the subject. These two attitudes, prudence and protection, are characteristic of FTA mitigations (see Table 5). In the second example, Carte Noire uses the same type of mitigation ("we know that"). Faced with this mitigated FTA, the criticism of the user (round 2) may constitute a reaction to the perception of a threat (Chen, 2015; Peña and Brody, 2014). However, the consumer also seems to be trying to mitigate their own FTAs by using formulas of depersonalisation ("Nobody finds that shocking.....") and generalisation ("everyone"). Thus, compliance with the rules of face-work allows the exchange to take place regardless, here following the principle of freedom of interpersonal communication. This phenomenon is observed notably when the interlocutors consider it useful to preserve their relationship (Mauney and Jeon, 2014).

\section{Production of FFAs in brand conversation: from gratitude to scepticism}

Production of FFAs by brands. In their conversations with consumers, brands use the entire available range of FFAs. Based on Brown and Levinson's typology of FFAs (1987), our analysis of brand conversations reveals three forms of FFAs associated with eight linguistic practices (Table 6).

\section{[Insert Table 6]}

Brands may seek to cooperate with consumers to demonstrate a kind of proximity, or try to increase consumer satisfaction by showing understanding and sympathy (e.g., "We're glad

\footnotetext{
${ }^{7}$ All quotes are reproduced as posted.
} 
that you like Joko and it makes you laugh (-)"). Finally, their FFAs are frequent, ranging from signs of attention and humour, to phrases of approval and compliments (e.g., "It's because we have great ambassadors!!").

Perception of the FFAs: gratitude and scepticism. Our results reveal ambivalent consumer perceptions of the production of FFAs, which are supposed to respond to the interlocutor's need for recognition. Our data analysis shows that brands implement strategies to flatter consumers that often generate a feeling of gratitude. For example, Sylvie appreciates the fact that the Starbucks brand shows a genuine interest in the contributions of consumers on its co-creation site:

"I like it. I think it's great. You can see the ideas that they're working on. I imagine it means they're works in progress (...) It's good, it's nice. Because there are people who have reacted and the brand has reacted back. That's what I like really (...) Here the fact that the guy, in his response, is quite restrained, he says "we thought about it, but it's a bit complicated, we don't know, but we will talk about it again with our teams" and then the comments of the people, here I'm scrolling all the way down. I feel like I know what's happening. (...). It's clearer (...), I don't feel like they just don't care what I think (laughs). (...) I feel like I'm involved (...). I feel like I'm part of the process.” (Sylvie).

This account illustrates the use of inclusion-type FFAs (see Table 6) and supports the idea that techniques aimed at flattering consumers, in particular by including them within a community, encourage positive attitudes among those who have suggested ideas to the brand (Fombelle et al., 2016). In addition, Sylvie describes her satisfaction as an observer of interactions, due to the "restrained" and inclusive responses of the brand representative. Like Le Petit Marseillais on its Facebook page, as in the example presented below, brands sometimes respond individually to consumers, flattering them with FFAs containing "approvals" and "compliments":

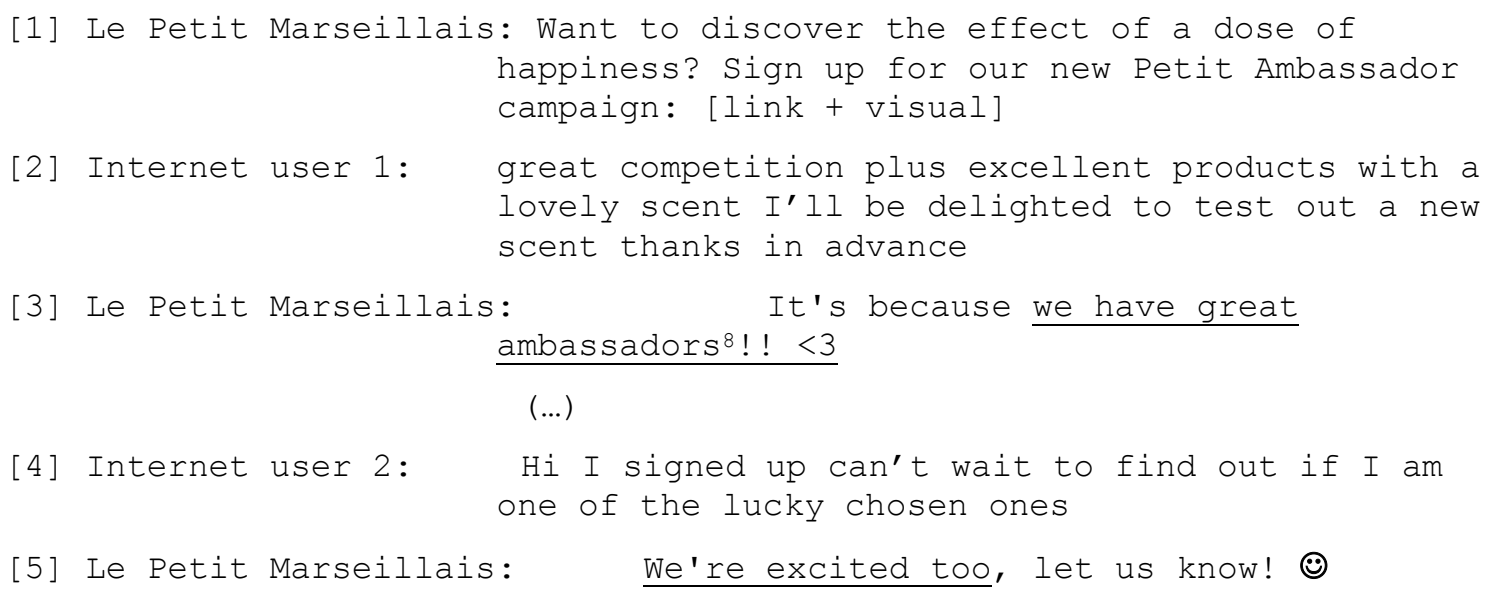

\footnotetext{
8 The passages are underlined by the authors.
} 


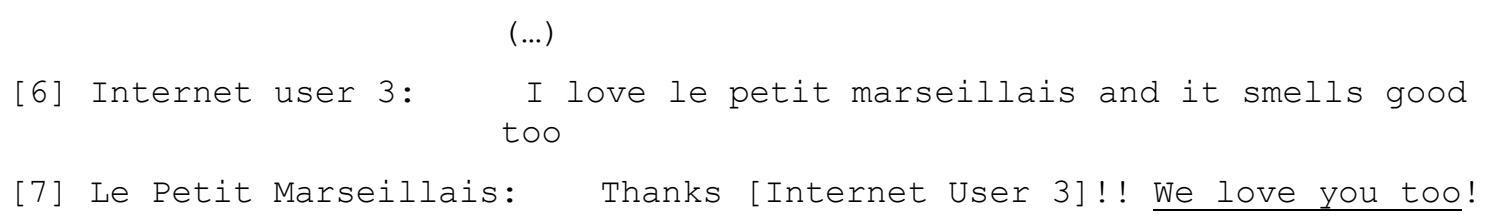

This conversation begins with a questioning formula that allows the brand to mitigate the product FTA which is positioned immediately after ("Sign up"). Then, the brand uses formulas that flatter consumers (turns 3 and 7) and shows them approval and support (turn 5). The function of these linguistic acts is to "give face" to consumers (Kerbrat-Orecchioni, 2010). They contribute to reinforcing the positive atmosphere of the conversation and ensuring the interaction order. However, FFAs do not always generate positive reactions. In particular, deference - a very strong form of politeness observed in several brand interventions - seems risky. Indeed, long and detailed responses from brands sometimes contrast with the brevity or even harshness of consumers' messages. These exchanges may raise doubts about the brand's sincerity or cause a form of exasperation, as Justine explains here:

"People see that there are trolls who post stupid comments, and the way the brand responds can also be to its credit (...). It's not worth being sweet or spending hours with a troll. A very polite response, but a little something that sets the record straight too. Other people are pleased to see that too, that you have someone who is a little clever behind you, that it's not all sugary sweet: "Oh well, we're really very sorry". It can be a firm response, if the company is in the right, because sometimes it is right, just a short, calm response. (...) I don't think there's any point in trying to respond to exhausting people for hours on end." (Justine).

Justine appreciates direct and sincere conversations, without pretences. This account goes hand in hand with the idea that overly flattering responses can feel like manipulation (Wang and Chaudhry, 2018). From the face-work perspective of, these messages can be considered "hyperpoliteness", defined by the presence of markers that are excessive compared to the standards at play in a given context (Kerbrat-Orecchioni, 2010). This is in line with the idea that non-compliance with conversational standards is potentially harmful for brands, even in the form of an FFA. In addition, our analysis shows that brand hyperpoliteness can occur in response both to negative messages and positive messages. For example, Lionel comments on an interaction between the official Gaumont Pathé cinema chain account and an Internet user, revealing a kind of irritation with the brand:

"When a brand comes into my world to try to create a so-called friendly bond, "what did you think of the film? ", that goes too far. (...) Leave me alone. What I thought of the film is my business, I might share it with my friends, if I want to, but I don't want a brand, a company to ask me what I thought of the film. (...) This is my space, this is my world. It's also a kind of modesty. I don't want to tell everyone what I think about everything and... 
For me, it wouldn't be very... And also, asking me the question is pushing me to answer when I have absolutely no desire to answer. I find it annoying." (Lionel).

Lionel considers the brand intervention to be inappropriate and intrusive, even though expressions of attention and friendliness are supposed to be FFAs (see Table 6). This account shows that the commercial nature of the brand affects conversation rules. Brand interventions, even when made up of FFAs, can be misinterpreted by both the recipient and spectators because they are generally considered to have a commercial purpose. This observation complements previous research which has shown that some consumers may negatively judge brands that show particularly strong politeness in their advertising (Sundar and Cao, 2020).

In summary, our results reveal the ambivalent reactions of consumers during their interactions with brands, which echoes the work of Goffman (1967) according to whom a compliment or reward can plunge the recipient into confusion or a feeling of unhappiness, while an individual can remain positive and appreciate a negative response if it is perceived as appropriate for the context.

\section{Discussion and conclusion}

Based on an analysis of 151 online conversations involving six brands in three business sectors and a series of semi-structured interviews with 12 consumers, this research contributes to enriching the literature on brand-consumer interactions by extending face-work theory of to the context where one of the interlocutors is a brand. Furthermore, our results lead us to make recommendations in the areas of brand and community management.

\section{Contribution to the literature on brand-consumer online interactions}

Our research identifies the diversity of FTAs, mitigations and FFAs used by brands, which are in line with the Brown and Levinson typology (1987), and highlights the ambivalence that these different linguistic practices can generate. Firstly, we show that the use of FTAs by brands can have negative consequences for the continuation of the interaction. Furthermore, in accordance with the rules of interpersonal conversation, brands have the opportunity to mitigate these FTAs or produce FFAs to meet individuals' needs for freedom and recognition and to continue the exchange. Likewise, our results reveal that brand FTAs do not necessarily generate negative perceptions, particularly if the consumers have specific relationships with a brand and appreciates being solicited by a brand that they respect.

Regarding the FFAs used by brands, they generally generate a feeling of gratitude, but can also induce a feeling of suspicion in the eyes of consumers who may, in a commercial 
context, perceive a lack of sincerity from the brand. Furthermore, whereas marketing research had previously only identified the presence of FFAs in the case of reducing the negative effects of FTAs (Fombelle et al., 2016), our study shows that FFAs are also produced in response to positive comments from consumers, i.e. in a context that is already favourable to a positive outcome of the interaction.

By focusing on conversational norms and revealing the consequences of their respect or transgression by brands, we respond to the call from Smith and Rose (2020), who found that the role of norms of use in online relationships had not been sufficiently studied and was an important avenue for research. Our research complements the literature by examining the conversational model of online conversation in light of face-work theory and taking into account both participants and spectators. By focusing on FTAs, mitigations and FFAs, we also respond to a call by Villarroel Ordenes et al. (2019), who state that researchers should conduct detailed analyses of messages from brands that simultaneously include multiple intentions.

\section{Contribution to face-work theory}

Our analysis shows that interactions between brands and consumers incorporate face-work strategies and mechanisms similar to those observed in interactions between individuals. However, our results also suggest that the relationship with the brand as well as the symbolic nature of the brands, combined with the commercial context of exchanges, can call into question the principles of face-work.

As explained above, our research shows that brand FTAs do not necessarily hinder continued interaction. This phenomenon can be explained by the nature of the relationship with the brand. In fact, consumers could comply with the brand's instructions or at least not be offended due to considering that the risk of "losing face" with a brand they know is lower than the risk of losing face with an unknown brand. These results are consistent with the fact that web users tolerate informal language from brands they know, but not from an unknown brand (Gretry et al., 2017). They also reveal that the conditions for applying face-work rules also prevail in the case of brand conversations: face-work strategies can be more relaxed when there is a certain familiarity between the participants, as the risk of face loss is reduced in the presence of familiar individuals (Brown and Levinson, 1987).

However, the symbolic nature of a brand as a contact may also explain the positive assessments of FTAs in certain circumstances. In those cases, consumers would ignore the presence of a "real" person (e.g., a community manager) at the helm of the brand's accounts by virtue of the phenomenon of "suspension of disbelief", which sees consumers participate in 
creating meaning by accepting the fictional element of the brand's narrative (Benmoussa and Maynadier, 2013). By putting themselves in a situation of dialogue with "the brand", as a symbolic object and not a human person, consumers could lessen the risk of loss of face inherent in an interpersonal relationship and therefore better accept the violation of face-work norms by brands, particularly when they produce FTAs. This situation echoes the fact that consumers, particularly the youngest among them, prefer to interact with a virtual agent rather than a human, in order to maintain a sense of control (Köhler et al., 2011).

With regard to FFAs, our results show that they can sometimes generate negative perceptions. Of course, consumers involved with a brand can feel flattered and surprised by the fact that their object of devotion is addressing them (Schamari and Schaefers, 2015). However, our research shows that flattering acts produced by brands can be perceived as insincere, because they take place in the context of a communication whose consumers are aware of the underlying objectives. Thus, beyond the phenomenon of hyperpoliteness (Kerbrat-Orecchioni, 2010), which is already known in the case of interactions between individuals, the negative reactions of consumers to brand FFAs can be explained by the commercial context of exchanges, which may cast doubt on the intentions of the brand (Wang and Chaudhry, 2018).

In conclusion, this research contributes to the literature on face-work by showing that, on the one hand, the rules of face-work apply globally to brand conversational practices on social media, but that, on the other hand, the relationship with the brand, the symbolic nature of the brand and the underlying commercial context can explain positive reactions and perceptions of FTAs, and the opposite for FFAs.

\section{Managerial implications}

This research allows practitioners to better understand the perception of three main language practices (FTAs, FTA mitigations and FFAs) in brand conversation, thus offering new perspectives for building brand-consumer relationship and for community management based on an informed use of FTAs, mitigations and FFAs. We thus offer a decision-making tool in the form of recommendations for each of the conversational forms presented in the first part of this article (Table 7).

\section{[Insert Table 7]}

(1) In proactive host brand conversations, brands have the upper hand and can adapt their interaction style to their identity. On the other hand, FTAs must be used sparingly. While FTAs 
seem to work in the case of messages intended for consumers who already follow a brand's page, our results show that they should be avoided in sponsored posts, which reach a wider audience. In these circumstances, community managers should favour less intrusive formulae (e.g., a suggestion rather than an order), accompanying FTAs with mitigations (e.g., questioning formulae rather than imperative ones) and/or FFAs.

(2) The conversational environment of a reactive host brand seems conducive to responding to the need for consumer recognition. Community spaces are by nature inclusive and cooperative, such as co-creation website where consumers can suggest ideas for new products and have the opportunity to express themselves and have their contribution recognised. To respond further to the consumer's needs for recognition, brands can use FFAs, such as signs of approval and expressions of sympathy.

(3) In the case of a proactive guest brand conversation, the brand must take certain precautions because it is intervening unsolicited in spaces that it does not control. The interaction style must therefore be generally factual and of a neutral tone, avoiding both overly intrusive FTAs and overly supportive FFAs. Interventions within these spaces must ensure that the consumers' perception of an intrusion on their territory is minimised. Mitigations should therefore be given priority here, for example offering options and asking questions.

(4) Finally, in conversations where the brand is a reactive guest, it is advisable to adapt to the consumer's situation and the issue. In particular, in the context of customer assistance or answering questions, it is better to favour a direct and efficient style, which may therefore include unmitigated FTAs such as advice and requests, or even orders, if this can result in the rapid resolution of the problem raised by a customer.

The use of face-work strategies in online brand-consumer interactions may have seemed quite natural, since there is generally a human being behind the brand's posts, for example a community manager, who has been conditioned by their personal experience of the rules of interindividual communication. However, it is clear that these interactions do not always take place in a satisfactory manner for brands. The rules of face-work may ultimately not be so well known or mastered by practitioners in a commercial context. Our results therefore invite practitioners to better take into account the principles of interpersonal conversation. Awareness training for these rules could be offered to all employees who are in contact with consumers on the Internet. 


\section{Limits and avenues for research}

The exploratory nature of this study opens up new prospects for research. After identifying the diversity of brand linguistic practices and analysing the ambivalence of the perceptions and reactions they generate, it would be important to identify the individual and contextual variables that could play a role in the use of these processes. For example, it would be useful to better understand how the perception of FTAs and FFAs can be altered by: (1) the type of Internet users concerned (participants or spectators), (2) the subject of the conversation (more or less linked to commercial elements), and (3) the type of relationship maintained with the brand. In particular, on this last point, future research could seek to better understand the conditions under which the risk of loss of face is more or less significant (e.g., familiarity with or attachment to the brand) so as to complete the criteria proposed by Brown and Levinson (1987), namely the power relationship as well as the social and cultural statuses of the interlocutors. Other studies could be carried out to take cultural differences into account, which would thus complement the work of Hudson et al. (2015) showing how cultural traits change the influence of interactions and the quality of the brand-consumer relationship.

Since our results have shown contrasting reactions by consumers to the way brands comply or violate conversational norms, future research could more specifically focus on how the application of these rules impacts the perception of the brand. Following research that shows that interactions between customers and contact staff are perceived differently depending on the consistency between the personality of the employees and that of the brand (Sirianni et al., 2013), it could be interesting to understand how the more or less strict compliance with facework rules by brands makes it possible to express and/or enrich their personality. More specifically, research could attempt to understand how FTAs, mitigations or FFAs change or shape the image of competence and warmth, two important facets of brand personality (Fournier and Alvarez, 2012). From this perspective, it would also be useful to deepen the analysis of each of the face-work strategies (FTAs, FTA mitigations and FFAs) by introducing the different nuances identified in the literature and presented in this research in tables 4, 5 and 6.

Furthermore, although our research is based on the most widely used social media platforms, it would be important to develop research on brand conversations on platforms that have more recently emerged, such as TikTok for example. Moreover, consumer-brand interactions are also developing in private conversations, on platforms such as Snapchat, Messenger and WhatsApp. It therefore seems important to better understand how conversational rules apply in a context where the perspective of the other is no longer part of the 
equation. In the context of private interactions with a brand, are these rules strengthened, or on the contrary relaxed, compared to interactions in public?

In addition, insofar as marketing faces the constant development of new interactive tools, it would be interesting to continue this analysis of brand conversation in the light of face-work theory and in the context of smart objects and augmented or virtual reality devices. Our results could in particular be verified in the context of automated conversations using artificial intelligence, such as for example in the case of "chatbots", conversational agents installed within instant messaging systems in the form of text interfaces or accompanying smart speakers in the form of voice interfaces. These trends are among those that will significantly impact marketing practices, particularly on social media (Appel et al., 2020). Thus, as a continuation of this study of linguistic practices in brand conversation, it will now be important, for researchers as well as for practitioners, to more globally integrate the analysis of written or oral conversation between brands and consumers.

\section{Acknowledgements}

First of all, we would like to thank the editor in chief, the associate editor in chief and the three anonymous readers for their positive and constructive comments, which enabled us to improve our manuscript throughout the evaluation process. This research was carried out under the auspices of the COACTIS laboratory (Université Lumière Lyon 2 and Université Jean Monnet Saint-Etienne) and the Brands \& Values Chair at IAE Paris-Sorbonne. We would like to thank the members of these institutions for their stimulating contributions. We would also like to thank Entrecom, a member of the Brands \& Values Chair, for its support for this research.

\section{References}

Appel G, Grewal L, Hadi R, et al. (2020) The future of social media in marketing. Journal of the Academy of Marketing Science 48(1): 79-95. DOI: 10.1007/s11747-019-00695-1

Arnould EJ et Wallendorf M (1994) Market-oriented ethnography: interpretation building and marketing strategy formulation. Journal of Marketing Research 31(4): 484-504. DOI: $10.1177 / 002224379403100404$

Bardin L (1977) L'analyse de contenu. Paris: Presses universitaires de France.

Bedijs K, Held G et Maaß C (2014) Introduction: face work and social media. In: Bedijs K, Held G, et Maaß C (eds) Face work and social media. Münster: LIT, pp. 9-28.

Benmoussa F-Z et Maynadier B (2013) Brand storytelling: entre doute et croyance. Une étude des récits de la marque Moleskine. Décisions Marketing: 119-128. DOI: 
10.7193/dm.070.119.128

Berthelot-Guiet K (2011) Extension du domaine de la conversation: discours de marque et

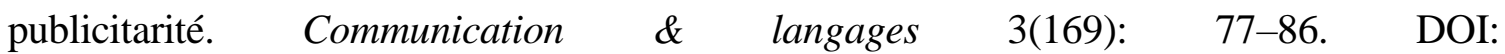
$10.4074 / \mathrm{S} 0336150011003073$

Bouillé J, Basso F et Robert-Demontrond P (2016) La rhétorique incarnée de l'activisme consumériste au regard de la théorie de la métaphore conceptuelle : étude exploratoire et perspectives de recherche. Recherche et Applications en Marketing 31(2): 86-112. DOI: $10.1177 / 0767370115622951$

Breitsohl J, Kunz WH et Dowell D (2015) Does the host match the content? A taxonomical update on online consumption communities. Journal of Marketing Management 31(9): 1040-1064. DOI: 10.1080/0267257X.2015.1036102

Brown P et Levinson S (1987) Politeness: some universals in language use. Studies in interactional sociolinguistics 4. Cambridge: Cambridge University Press.

Campbell C, Ferraro C et Sands S (2014) Segmenting consumer reactions to social network marketing. European Journal of Marketing 48(3): 432-452. DOI: 10.1108/EJM-03-20120165

Chen GM (2015) Losing face on social media: threats to positive face lead to an indirect effect on retaliatory aggression through negative affect. Communication Research 42(6): 819838. DOI: $10.1177 / 0093650213510937$

Chen K-J, Lin J-S, Choi JH, et al. (2015) Would you be my friend? An examination of global marketers' brand personification strategies in social media. Journal of Interactive Advertising 15(2): 97-110. DOI: 10.1080/15252019.2015.1079508

Cruz RE, Leonhardt JM et Pezzuti T (2017) Second person pronouns enhance consumer involvement and brand attitude. Journal of Interactive Marketing 39: 104-116. DOI: 10.1016/j.intmar.2017.05.001

De Montety C et Patrin-Leclère V (2011) La conversion à la conversation: le succès d'un succédané. Communication \& langages 3(169): 23-37. DOI: $10.4074 / \mathrm{S} 0336150011003036$

Dessart L, Veloutsou C et Morgan-Thomas A (2015) Consumer engagement in online brand communities: a social media perspective. Journal of Product \& Brand Management 24(1): 28-42. DOI: 10.1108/JPBM-01-2015-0790

Drouet M (2011) De «la communication » à « la conversation» : vers un nouveau paradigme en publicité? Communication \& langages 2011(169): 39. DOI: 10.4074/S0336150011003048 
Fombelle PW, Bone SA et Lemon KN (2016) Responding to the 98\%: face-enhancing strategies for dealing with rejected customer ideas. Journal of the Academy of Marketing Science 44(6): 685-706. DOI: 10.1007/s11747-015-0469-y

Fournier S et Alvarez C (2012) Brands as relationship partners: Warmth, competence, and inbetween. Journal of Consumer Psychology 22(2), 177-185. DOI: 10.1016/J.JCPS.2011.10.003

Fournier S et Avery J (2011) The uninvited brand. Business Horizons 54(3): 193-207. DOI: 10.1016/j.bushor.2011.01.001

Glaser BG et Strauss AL (1967) The discovery of grounded theory: strategies for qualitative Research. Aldine. DOI: 10.2307/2575405

Godes D et Mayzlin D (2004) Using online conversations to study word-of-mouth communication. Marketing Science 23(4): 545-560. DOI: 10.1287/mksc.1040.0071

Goffman E (1955) On face-work: an analysis of ritual elements in social interaction. Psychiatry: Journal for the Study of Interpersonal Processes 18(3): 213-231. DOI: $10.1162 / 15241730360580159$

Goffman E (1967 [1974]) Les Rites d'interaction. Paris : Editions de Minuit.

Goffman E (1973) La Mise En Scène de La Vie Quotidienne. 2: Les Relations En Public. Paris: Editions de Minuit

Goulding C (1999) Consumer research, interpretive paradigms and methodological ambiguities. European Journal of Marketing 33(9/10): 859-873. DOI: 10.1108/03090569910285805

Gretry A, Horváth C, Belei N, et al. (2017) 'Don't pretend to be my friend!' When an informal brand communication style backfires on social media. Journal of Business Research 74: 77-89. DOI: 10.1016/j.jbusres.2017.01.012

Griffiths M et Mclean R (2015) Unleashing corporate communications via social media: A UK study of brand management and conversations with customers. Journal of Customer Behaviour 14(2): 147-162. DOI: 10.1362/147539215X14373846805789

Hamilton M, Kaltcheva VD et Rohm AJ (2016) Hashtags and handshakes: consumer motives and platform use in brand-consumer interactions. Journal of Consumer Marketing 33(2): 135-144. DOI: 10.1108/JCM-04-2015-1398

Hine C (2007) Multi-sited ethnography as a middle range methodology for contemporary STS. Science, Technology, \& Human Values 32(6). 652-671. DOI: 10.1177/0162243907303598

Homburg C, Ehm L et Artz M (2015) Measuring and managing consumer sentiment in an online community environment. Journal of Marketing Research 52(5): 629-641. DOI: 10.1509/jmr.11.0448 
Hudson S, Huang L, Roth MS, et al. (2015) The influence of social media interactions on consumer-brand relationships: a three-country study of brand perceptions and marketing behaviors. International Journal of Research in Marketing 1(33): 27-41. DOI: 10.1016/j.ijresmar.2015.06.004

Hutter K, Hautz J, Dennhardt S, et al. (2013) The impact of user interactions in social media on brand awareness and purchase intention: the case of MINI on Facebook. Journal of Product \& Brand Management 22(5/6): 342-351. DOI: 10.1108/JPBM-05-2013-0299

Kerbrat-Orecchioni C (1992) Les interactions verbales. Tome II. Paris: A. Colin.

Kerbrat-Orecchioni C (1998) La notion d'interaction en linguistique : origine, apports, bilan. Langue française 117: 51-67. DOI: 10.3406/lfr.1998.6241

Kerbrat-Orecchioni C (2005) Le discours en interaction. Paris: Armand Colin,.

Kerbrat-Orecchioni C (2007) L'analyse du discours en interaction: quelques principes méthodologiques. Limbaje si comunicare IX: 13-32.

Kerbrat-Orecchioni C (2010) L'impolitesse en interaction : aperçus théoriques et étude de cas. Lexis Special (2): 35-60.

Kerssen-Griep J, Trees AR et Hess JA (2008) Attentive facework during instructional feedback: key to perceiving mentorship and an optimal learning environment. Communication Education 57(3): 312-332. DOI: 10.1080/03634520802027347

Köhler CF, Rohm AJ, de Ruyter K et al. (2011) Return on interactivity: the impact of online agents on newcomer adjustment. Journal of Marketing 75(2): 93-108. DOI: 10.1509/jmkg.75.2.93

Kozinets RV. (2010) Netnography: doing ethnographic research online. Londres: Sage Publications.

Kumar A, Bezawada R, Rishika R, et al. (2016) From social to sale: the effects of firmgenerated content in social media on customer behavior. Journal of Marketing 80(1): 7-25. DOI: 10.1509/jm.14.0249

Labrecque LI (2014) Fostering consumer-brand relationships in social media environments: the role of parasocial interaction. Journal of Interactive Marketing 28(2): 134-148. DOI: 10.1016/j.intmar.2013.12.003

Li X (Shirley), Chan KW et Kim S (2018) Service with emoticons: how customers interpret employee use of emoticons in online service encounters. Journal of Consumer Research 45(March): 1-50. DOI: 10.1093/jcr/ucy016

Liu Y et Shrum LJ (2002) What is interactivity and is it always such a good thing? Implications of definition, person, and situation for the influence of interactivity on advertising 
effectiveness. Journal of Advertising 31(4): 53-64. DOI: 10.1080/00913367.2002.10673685

Mauney S et Jeon L (2014) "I love you but I disagree": politeness and politics in computermediated discourse. Rice Working Papers in Linguistics, 5.

http://hdl.handle.net/1911/78540

Michel G (2017) Au coeur de la marque - 3ème éd.: les clés du management des marques. Paris: Dunod.

Peña J et Brody N (2014) Intentions to hide and unfriend Facebook connections based on perceptions of sender attractiveness and status updates. Computers in Human Behavior 31(1): 143-150. DOI: 10.1016/j.chb.2013.10.004

Sacks H, Schegloff EA et Jefferson G (1974) A simplest systematics for the organization of turn taking for conversation. Language 50(4): 696-735. DOI: 10.2307/412243

Schamari J et Schaefers T (2015) Leaving the home turf: how brands can use webcare on consumer-generated platforms to increase positive consumer engagement. Journal of Interactive Marketing 30: 20-33. DOI: 10.1016/j.intmar.2014.12.001

Schegloff EA et Sacks H (1973) Opening up closings. Semiotica 8(4): 289-327.

Simon F et Tossan V (2018) Does brand-consumer social sharing matter? A relational framework of customer engagement to brand-hosted social media. Journal of Business Research 85: 175-184. DOI: 10.1016/j.jbusres.2017.12.050

Sirianni NJ, Bitner, MJ, Brown, SW et Mandel, N (2013) Branded service encounters: Strategically aligning employee behavior with the brand positioning. Journal of Marketing 77(6), 108-123. DOI:_10.1509/jm.11.0485

Smith AN, Fischer E et Yongjian C (2012) How does brand-related user-generated content differ across YouTube, Facebook, and Twitter? Journal of Interactive Marketing 26(2): 102-113. DOI: 10.1016/j.intmar.2012.01.002

Smith LW et Rose RL (2020) Service with a smiley face: emojional contagion in digitally mediated relationships. International Journal of Research in Marketing 37(2): 301-319. DOI: 10.1016/j.ijresmar.2019.09.004

Sundar A et Cao ES (2020) Punishing politeness: the role of language in promoting brand trust. Journal of Business Ethics 164: 39-60. DOI: 10.1007/s10551-018-4060-6

Van Dolen WM, Dabholkar PA et De Ruyter K (2007) La satisfaction envers les discussions en ligne de clients : l'influence des attributs technologiques perçus, des caractéristiques du groupe de discussion et du style de communication du conseiller. Recherche et Applications en Marketing 22(3): 339-358. DOI: 10.1177/076737010702200306 
Van Noort G et Willemsen LM (2012) Online damage control: the effects of proactive versus reactive webcare interventions in consumer-generated and brand-generated platforms. Journal of Interactive Marketing 26(3): 131-140. DOI: 10.1016/j.intmar.2011.07.001

Villarroel Ordenes F, Grewal D, Ludwig S, et al. (2019) Cutting through content clutter: how speech and image acts drive consumer sharing of social media brand messages. Journal of Consumer Research 45(5): 988-1012. DOI: 10.1093/jcr/ucy032

Wang Y et Chaudhry A (2018) When et how managers' responses to online reviews affect subsequent reviews. Journal of Marketing Research 55(2). American Marketing Association: 163-177. DOI: 10.1509/jmr.15.0511

Zemack-Rugar Y, Moore SG et Fitzsimons GJ (2017) Just do it! Why committed consumers react negatively to assertive ads. Journal of Consumer Psychology 27(3): 287-301. DOI: 10.1016/j.jcps.2017.01.002 
Appendix 1 - Main works on brand conversation

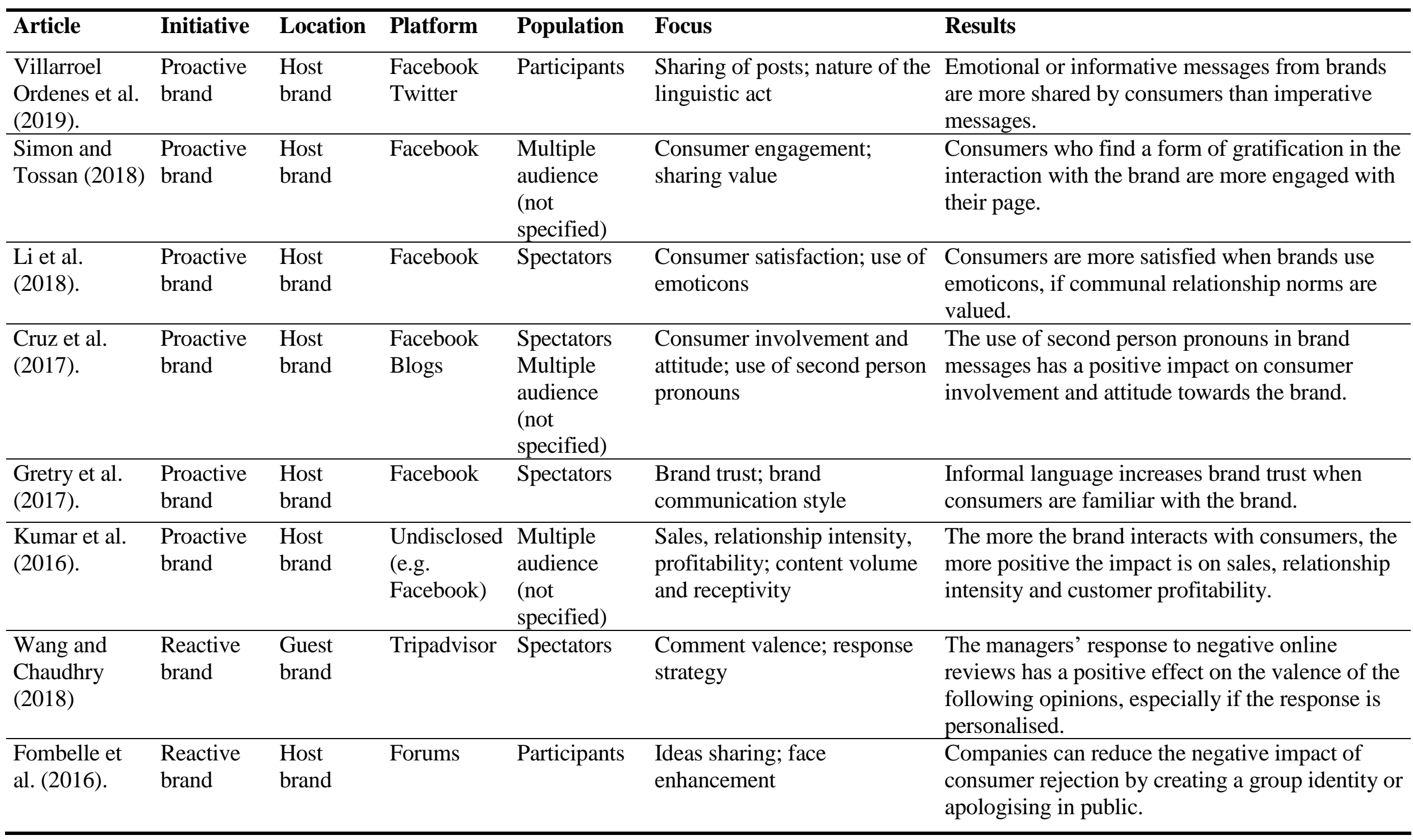




\begin{tabular}{|c|c|c|c|c|c|c|}
\hline $\begin{array}{l}\text { Homburg et } \\
\text { al. (2015). }\end{array}$ & $\begin{array}{l}\text { Reactive } \\
\text { brand }\end{array}$ & $\begin{array}{l}\text { Host } \\
\text { brand }\end{array}$ & Forums & Participants & $\begin{array}{l}\text { Brand sentiment; level of } \\
\text { company engagement }\end{array}$ & $\begin{array}{l}\text { The more companies participate in conversations, } \\
\text { the more positive the attitude towards them, up to } \\
\text { a point. }\end{array}$ \\
\hline $\begin{array}{l}\text { Schamari and } \\
\text { Schaefers } \\
(2015)\end{array}$ & $\begin{array}{l}\text { Reactive } \\
\text { brand }\end{array}$ & $\begin{array}{l}\text { Host and } \\
\text { guest } \\
\text { brand }\end{array}$ & $\begin{array}{l}\text { Facebook } \\
\text { Forums }\end{array}$ & Spectators & $\begin{array}{l}\text { Consumer engagement; } \\
\text { response strategy }\end{array}$ & $\begin{array}{l}\text { The response of brands to positive comments on } \\
\text { consumer-operated platforms has a positive } \\
\text { impact on their intention to engage. }\end{array}$ \\
\hline $\begin{array}{l}\text { Breitsohl et } \\
\text { al. }(2015) \text {. }\end{array}$ & $\begin{array}{l}\text { Proactive } \\
\text { and } \\
\text { reactive } \\
\text { brand }\end{array}$ & $\begin{array}{l}\text { Host and } \\
\text { guest } \\
\text { brand }\end{array}$ & Forums & Participants & $\begin{array}{l}\text { Frequency of consumer posts; } \\
\text { perceived benefits }\end{array}$ & $\begin{array}{l}\text { The perceived benefits of exchanges has a more } \\
\text { positive effect on the frequency of posting within } \\
\text { communities managed by brands (vs. by } \\
\text { consumers). }\end{array}$ \\
\hline $\begin{array}{l}\text { Van Noort } \\
\text { and } \\
\text { Willemsen, } \\
(2012)\end{array}$ & $\begin{array}{l}\text { Reactive } \\
\text { brand }\end{array}$ & $\begin{array}{l}\text { Host and } \\
\text { guest } \\
\text { brand }\end{array}$ & Blogs & Spectators & $\begin{array}{l}\text { Brand evaluation; response } \\
\text { strategy }\end{array}$ & $\begin{array}{l}\text { Brands" "reactive" responses to negative } \\
\text { comments result in a more positive brand } \\
\text { evaluation than when there is no response. }\end{array}$ \\
\hline $\begin{array}{l}\text { Smith et al., } \\
\text { (2012) }\end{array}$ & $\begin{array}{l}\text { Not } \\
\text { specified }\end{array}$ & $\begin{array}{l}\text { Not } \\
\text { specified }\end{array}$ & $\begin{array}{l}\text { Facebook } \\
\text { Twitter } \\
\text { YouTube }\end{array}$ & Participants & $\begin{array}{l}\text { UGC volume; social media } \\
\text { type; brand presence strategy }\end{array}$ & $\begin{array}{l}\text { User generated content volume is higher when } \\
\text { the brands offer opportunities and reasons to be } \\
\text { contacted. }\end{array}$ \\
\hline This research & $\begin{array}{l}\text { Proactive } \\
\text { and } \\
\text { reactive } \\
\text { brand }\end{array}$ & $\begin{array}{l}\text { Host and } \\
\text { guest } \\
\text { brand }\end{array}$ & $\begin{array}{l}\text { Facebook } \\
\text { Twitter } \\
\text { Instagram } \\
\text { LinkedIn } \\
\text { YouTube } \\
\text { Blogs } \\
\text { Forums }\end{array}$ & $\begin{array}{l}\text { Spectators } \\
\text { and } \\
\text { participants }\end{array}$ & $\begin{array}{l}\text { Compliance with } \\
\text { conversational norms by } \\
\text { brands; behaviour and } \\
\text { perceptions of Internet users }\end{array}$ & $\begin{array}{l}\text { Facework principles (FTAs, mitigations, FFAs) } \\
\text { are used in brand conversation. The relationship } \\
\text { with the brand as well as the symbolic and } \\
\text { commercial nature of the brand explain positive } \\
\text { reactions to FTAs and negative reactions to } \\
\text { FFAs. }\end{array}$ \\
\hline
\end{tabular}


Figure 1 - The different facework strategies based on the risk of losing face (adapted from Brown et Levinson, 1987, and Kerbrat-Orecchioni, 1992)

If the risk of losing If the risk of losing face is high face is low

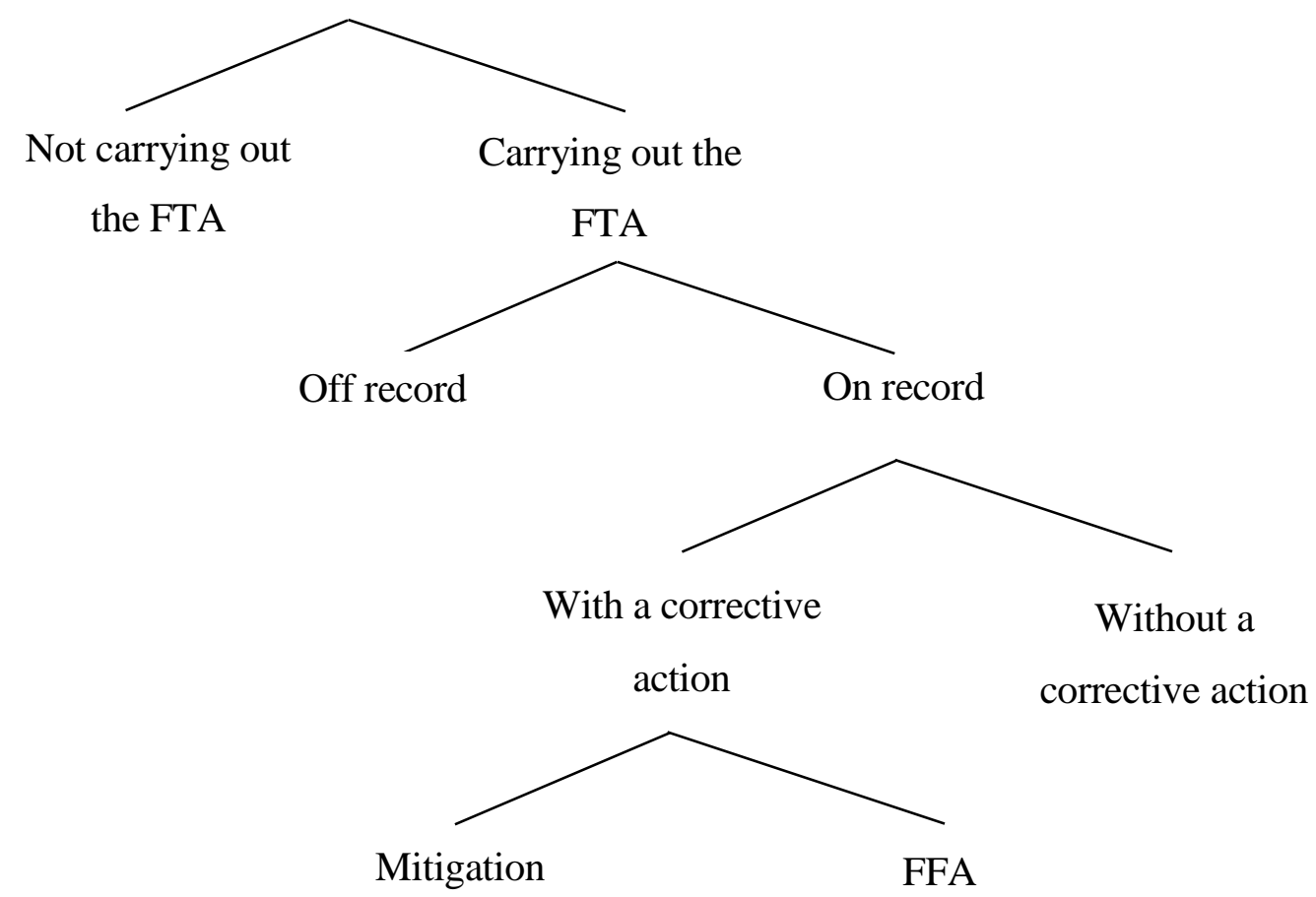


Table 1 - The different forms of brand conversation

\begin{tabular}{|c|c|c|}
\hline \multirow{2}{*}{$\begin{array}{l}\text { Conversation } \\
\text { initiatiation }\end{array}$} & \multicolumn{2}{|l|}{ Conversation location } \\
\hline & $\begin{array}{l}\text { Host brand conversing in online } \\
\text { spaces it controls }\end{array}$ & $\begin{array}{l}\text { Guest brand conversing in online } \\
\text { spaces it does not control }\end{array}$ \\
\hline \multirow{2}{*}{$\begin{array}{l}\text { Proactive brand } \\
\text { initiating the } \\
\text { conversation }\end{array}$} & $\begin{array}{l}\text { 1. Proactive-host brand } \\
\text { conversation }\end{array}$ & $\begin{array}{l}\text { 3. Proactive-guest brand } \\
\text { conversation }\end{array}$ \\
\hline & $\begin{array}{l}\text { Post by a brand on its social media } \\
\text { pages } \\
\text { (e.g.: Gretry et al. 2017; Kumar et } \\
\text { al. 2016). }\end{array}$ & $\begin{array}{l}\text { Post by a brand within online } \\
\text { communities or addressing } \\
\text { consumer accounts that have not } \\
\text { addressed it } \\
\text { (e.g.: Breitsohl et al., 2015; Wang } \\
\text { and Chaudhry, 2018). }\end{array}$ \\
\hline $\begin{array}{l}\text { Reactive brand } \\
\text { intervening in a } \\
\text { conversation initiated } \\
\text { by a consumer }\end{array}$ & $\begin{array}{l}\text { 2. Reactive-host brand } \\
\text { conversation } \\
\text { A brand's response to a consumer } \\
\text { posting in a brand-operated } \\
\text { community page. } \\
\text { (e.g.: Fombelle et al., 2016; } \\
\text { Homburg et al., 2015). }\end{array}$ & $\begin{array}{l}\text { 4. Reactive-guest brand } \\
\text { conversation } \\
\text { A brand's response to messages } \\
\text { from consumers sent to the brand } \\
\text { from their own accounts. } \\
\text { (e.g.: Schamari and Schaefers, } \\
\text { 2015; Van Noort and Willemsen, } \\
\text { 2012). }\end{array}$ \\
\hline
\end{tabular}


Table 2 - Conversational situations

\begin{tabular}{|c|c|c|c|c|}
\hline Method & Focus & Conversational form & Sector & Brand \\
\hline Online observation & $\begin{array}{l}\text { Brand } \\
\text { Face-work strategies; } \\
\text { Behaviour of participating } \\
\text { consumers }\end{array}$ & $\begin{array}{l}\text { Proactive host; } \\
\text { Reactive host; } \\
\text { Reactive guest; }\end{array}$ & $\begin{array}{l}\text { Food; Automotive; Hygiene- } \\
\text { Beauty }\end{array}$ & $\begin{array}{l}\text { Carte Noire; Joker; } \\
\text { Audi; Peugeot; Le Petit } \\
\text { Marseillais; Guerlain }\end{array}$ \\
\hline Interviews & $\begin{array}{l}\text { Perceptions consumers } \\
\text { (participants and } \\
\text { spectators) }\end{array}$ & $\begin{array}{l}\text { Proactive host; } \\
\text { Reactive host; } \\
\text { Proactive guest; } \\
\text { Reactive guest; }\end{array}$ & $\begin{array}{l}\text { Banking; Cinema; } \\
\text { Telecommunications; Fast } \\
\text { food; Miscellaneous }\end{array}$ & $\begin{array}{l}\text { Caisse d'Epargne; Gaumont- } \\
\text { Pathé; Free Mobile; Starbucks; } \\
\text { spontaneous quotes } \\
\text { (e.g.: Apple, Decathlon, BNP) }\end{array}$ \\
\hline
\end{tabular}


Table 3 - Respondent profile

\begin{tabular}{|c|c|c|c|c|}
\hline Name $^{9}$ & Age & $\begin{array}{l}\text { Family } \\
\text { situation }\end{array}$ & Level of education & Profession \\
\hline Alexis & 42 & Divorced & $\begin{array}{l}\text { Secondary } \\
\text { vocational }\end{array}$ & Municipal employee \\
\hline Antoine & 28 & Partnered & Graduate & Engineer \\
\hline Carole & 61 & Single & Undergraduate & Librarian \\
\hline Denis & 68 & Married & Graduate & Retired manager \\
\hline Guillaume & 39 & Divorced & $\begin{array}{l}\text { Secondary } \\
\text { vocational }\end{array}$ & Painter \\
\hline Judith & 69 & Married & Undergraduate & Retired assistant \\
\hline Justine & 30 & Single & Graduate & Naval officer \\
\hline Lionel & 32 & Single & Graduate & Retail \\
\hline Marc & 77 & Married & Graduate & Retired manager \\
\hline Marina & 38 & Partnered & Undergraduate & Tourist guide \\
\hline Sabine & 29 & Single & Undergraduate & HR employee \\
\hline Sylvie & 51 & Married & Secondary & $\begin{array}{l}\text { Administrative } \\
\text { employee }\end{array}$ \\
\hline
\end{tabular}

\footnotetext{
${ }^{9}$ Names have been changed.
} 
Table 4 - FTAs (Face Threatening Acts) used by brands

\begin{tabular}{|c|c|c|}
\hline $\begin{array}{l}\text { FTA } \\
\text { strategies }^{10}\end{array}$ & $\begin{array}{l}\text { Linguistic } \\
\text { practices }\end{array}$ & Examples \\
\hline \multirow[t]{5}{*}{ Command (a) } & Warning & $\begin{array}{l}\text { - Welcome to Petit Ambassadors. Please pay attention to spelling } \\
\text { out of respect for the brand and for the seriousness of the site. } \\
\text { Have a good day (Le Petit Marseillais, forum) }\end{array}$ \\
\hline & Advice & $\begin{array}{l}\text { - Internet user: I tried it and I would have liked the shower gel to } \\
\text { have a slightly stronger fragrance because you can't smell it. } \\
\text { - Le Petit Marseillais: If you think that there is a quality problem } \\
\text { with one of our products, please contact our consumer } \\
\text { department. (Le Petit Marseillais, Facebook) }\end{array}$ \\
\hline & Order & $\begin{array}{l}\text { - NOW IT'S YOUR TURN! Win a private screening with your } \\
\text { friends: LIKE, COMMENT or SHARE your favourite emoji! } \\
\text { (Carte Noire, Facebook) }\end{array}$ \\
\hline & Request & $\begin{array}{l}\text { - Can you send us your contact details and case number in a } \\
\text { DM } M^{11} \text { please? (Audi, Twitter) }\end{array}$ \\
\hline & Suggestion & $\begin{array}{l}\text { - On the occasion of World Happiness Day, Le Petit Marseillais } \\
\text { invites you to discover the new Les P'tits Bonheurs range! (Le } \\
\text { Petit Marseillais, blog) }\end{array}$ \\
\hline \multirow[t]{2}{*}{ Imposition (b) } & Gift & $\begin{array}{l}\text { - Le Petit Marseillais has decided to come with you and slip into } \\
\text { your suitcases for your weekends away and holidays in the sun } \\
\text { (Le Petit Marseillais, Facebook) }\end{array}$ \\
\hline & Promise & $\begin{array}{l}\text { - Obviously, you'll love it. Available in our online store (Guerlain, } \\
\text { Facebook) }\end{array}$ \\
\hline
\end{tabular}

(a) Brand commands aim to get consumers to take action. Commands tend to reduce the freedom of web users, who may feel compelled to take the action mentioned.

(b) Impositions consist of making unsolicited offers to consumers. These offers encroach on the territory of web users, who may feel indebted to the brand who imposes on them.

\footnotetext{
${ }^{10}$ The lists of FTA, mitigation, and FFA strategies and associated linguistic practices are adapted from Brown and Levinson (1987).

${ }^{11}$ Direct message (private message)
} 
Table 5 - FTA Mitigations (Face Threatening Act mitigations) used by brands

\begin{tabular}{|c|c|c|}
\hline $\begin{array}{l}\text { FTA } \\
\text { mitigation } \\
\text { strategies }\end{array}$ & Linguistic practices & Examples \\
\hline \multirow[t]{2}{*}{ Freedom (a) } & Apologies & $\begin{array}{l}\text { - Hello [User], we are sorry it has taken us so long to reply. } \\
\text { Could you tell us more? Thank you. (Audi, Twitter). }\end{array}$ \\
\hline & Offering options & $\begin{array}{l}\text { - Hello [User] Do not hesitate to contact us again or contact your } \\
\text { partner. (Audi, LinkedIn) }\end{array}$ \\
\hline \multirow[t]{2}{*}{ Protection (b) } & Depersonalisation & $\begin{array}{l}\text { - Movember starts today. Here are } 3 \text { great ways to support the } \\
\text { cause (Carte Noire, Facebook). }\end{array}$ \\
\hline & Generalisation & $\begin{array}{l}\text { - Audi S5 Coupé: you can see its sporty character at a glance. } \\
\text { (Audi, Instagram) }\end{array}$ \\
\hline \multirow[t]{2}{*}{ Caution (c) } & Dodge & $\begin{array}{l}\text { - Internet user: Oh @ AudiFrance, have you picked a side }{ }^{12} \\
\text { - Audi France: We've decided: a German car and a French } \\
\text { victory. (Audi, Twitter) }\end{array}$ \\
\hline & Question & $\begin{array}{l}\text { Can you figure out the exact number of oranges? Watch out, it } \\
\text { goes fast! (Joker, Facebook) }\end{array}$ \\
\hline
\end{tabular}

(a) The freedom strategy consists of giving control back to consumers, for example by acknowledging an error and/or offering the choice between different alternatives.

(b) The protection strategy allows consumers to decide whether they are the recipients or subjects of a message that contains a potential FTA, based on ambiguous wording.

(c) The caution strategy consists of expressing oneself in an indirect way to avoid any embarrassing situation or loss of face that could result from more direct wording.

\footnotetext{
${ }^{12}$ Reference to a France-Germany football match on the same day.
} 
Table 6 - FFAs (Face Flattering Acts) used by brands

\begin{tabular}{|c|c|c|}
\hline FFA strategies & $\begin{array}{l}\text { Linguistic } \\
\text { practices }\end{array}$ & Examples \\
\hline \multirow[t]{2}{*}{ Cooperation (a) } & Inclusion & $\begin{array}{l}\text { - Try to describe yourself in one word. Impossible you say? The } \\
\text { Audi Q2 is just like you (Audi, Twitter) }\end{array}$ \\
\hline & Optimism & $\begin{array}{l}\text { - Fingers crossed [Internet user]! } \\
\text { (Le Petit Marseillais, Facebook) }\end{array}$ \\
\hline \multirow[t]{2}{*}{ Satisfaction (b) } & Understanding & $\begin{array}{l}\text { - We understand your question. } \\
\text { (Carte Noire, Facebook) }\end{array}$ \\
\hline & Sympathy & $\begin{array}{l}\text { - We're glad that you like Joko and it makes you laugh }(;) \\
\text { (Joker, Facebook) }\end{array}$ \\
\hline \multirow[t]{4}{*}{ Valuation (c) } & Approval & $\begin{array}{l}\text { - Very good choice [user] }:) \\
\text { (Le Petit Marseillais, Facebook) }\end{array}$ \\
\hline & Attention & $\begin{array}{l}\text { - Hello, we are concerned about the quality of the services } \\
\text { provided in the Peugeot network, and we regret the } \\
\text { inconvenience you experienced while using your Peugeot. } \\
\text { (Peugeot, Facebook) }\end{array}$ \\
\hline & Compliments & $\begin{array}{l}\text { - It's because we have great ambassadors!! } \\
\text { (Le Petit Marseillais, Facebook) }\end{array}$ \\
\hline & Humour & $\begin{array}{l}\text { - Cat's got our tongue, tell us everything! } \\
\text { (Peugeot, Twitter) }\end{array}$ \\
\hline
\end{tabular}

(a) The cooperation strategy consists of engaging consumers in storytelling or actions and/or creating a positive environment between them and the brand.

(b) The satisfaction strategy consists of maximising the perceived satisfaction of consumers during the conversation, by showing support and being friendly.

(c) The valuation strategy consists of promoting consumers more or less directly, with the aim of obtaining a favourable attitude from them. 
Table 7 - Recommendations for linguistic practices in the four conversational forms

\begin{tabular}{lllll}
\hline & $\begin{array}{l}\text { (1) Proactive host } \\
\text { brand }\end{array}$ & $\begin{array}{l}\text { (2) Reactive host } \\
\text { brand }\end{array}$ & $\begin{array}{l}\text { (3) Proactive } \\
\text { guest brand }\end{array}$ & $\begin{array}{l}\text { (4) Reactive } \\
\text { guest brand }\end{array}$ \\
\hline $\begin{array}{l}\text { Face-work } \\
\text { strategies to }\end{array}$ & FFAs & FFAs (e.g., & Mitigations & Unmitigated \\
prioritise & Mitigations & attention paid to & (e.g., offer & FTAs \\
& $\begin{array}{l}\text { Avoid } \\
\text { unmitigated }\end{array}$ & internet users) & options) & $\begin{array}{l}\text { (e.g., advice, } \\
\text { requests) }\end{array}$ \\
& FTAs & & & \\
\hline
\end{tabular}

